\title{
Removal of phosphate from wastewater using coal slag
}

Nguyen Hoang Lam, Hoa Thai Ma, Mohammed J. K. Bashir, G. Eppe, Pramod Avti \& Tan Tai Nguyen

To cite this article: Nguyen Hoang Lam, Hoa Thai Ma, Mohammed J. K. Bashir, G. Eppe, Pramod Avti \& Tan Tai Nguyen (2020): Removal of phosphate from wastewater using coal slag, International Journal of Environmental Analytical Chemistry, DOI: 10.1080/03067319.2019.1708907

To link to this article: https://doi.org/10.1080/03067319.2019.1708907

\section{曲 Published online: 07 Jan 2020.}

Submit your article to this journal $₫$

Щ Article views: 44

Q View related articles $₫$

View Crossmark data ¿ 


\title{
Removal of phosphate from wastewater using coal slag
}

\author{
Nguyen Hoang Lam ${ }^{a}$, Hoa Thai Mab, Mohammed J. K. Bashirc, G. Eppe ${ }^{\text {, }}$, Pramod Avti ${ }^{\mathrm{e}}$ \\ and Tan Tai Nguyen ${ }^{f}$
}

\begin{abstract}
aBiotechnology and Environment Center, School of Agriculture and Aquaculture, Tra Vinh University, Tra

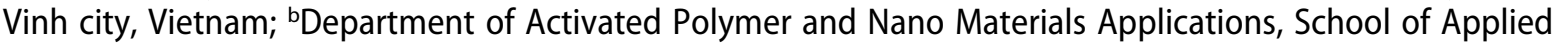
Chemistry, Tra Vinh University, Tra Vinh city, Vietnam; 'Faculty of Engineering and Green Technology (FEGT),

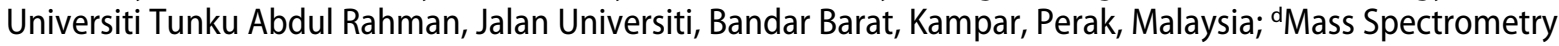
laboratory, MolSys Research Unit, University of Liège, Liège, Belgium; 'Department of Biophysics, Postgraduate Institute of Medical Education and Research (PGIMER), Chandigarh, India; fDepartment of Materials Science, School of Applied Chemistry, Tra Vinh University, Tra Vinh city, Vietnam
\end{abstract}

\begin{abstract}
Adsorption is an efficient, cost-effective, and eco-friendly method for the treatment of phosphorus from wastewater. This work presents the adsorptive removal of phosphate ions in aqueous solution using coal slag (CS) from a thermal power plan. The surface morphological analysis showed that the CS particles were around 50 $\mu \mathrm{m}$ with a surface area of $9.20 \mathrm{~m}^{2} \mathrm{~g}^{-1}$ and adsorption average pore width of $6.42 \mathrm{~nm}$, offering the high capability for phosphate ions adsorption. The optimising phosphate ions adsorption conditions were investigated based on various parameters, including contact time, $\mathrm{pH}$, and amount of absorbent. The experimental results showed that the maximum loading adsorption capacity was $21.63 \mathrm{mg} \mathrm{g}^{-1}$ in the concentration range of $0-30 \mathrm{mg} \mathrm{L}^{-1}$ under optimising conditions (i.e. $\mathrm{pH}$ of 6 , adsorbent dosage $\left(0.1 \mathrm{~g} \mathrm{vol}^{-1}\right.$ used) and contact time of $45 \mathrm{~min}$ ). Furthermore, the use of $C \bar{S}$ offers several benefits like reducing the sample pre-treatment steps for costly, less time-consuming and reliable methods.
\end{abstract}

\section{ARTICLE HISTORY}

Received 30 September 2019

Accepted 13 December 2019

\section{KEYWORDS}

Adsorption Capacity; Chemical Composition; Coal Slag; Phosphate lons; Isothermal

\section{Introduction}

Nowadays, the aquaculture industry is developing and is extremely important to the economy of Vietnam. Higher rate of phosphate production in recent years is one of the significant issues for the environment. Phosphorus can stimulate the growth of an aquatic organism, including macro and microorganism, which can cause eutrophication [1]. Previously, the only available adsorption techniques were based on high organic wastewater treatment including advanced oxidation processes [2], activated sludge treatment [3] and biological contact oxidation [4], which were adequate for removal of organic carbon and nitrogen in wastewater. However, those methods were not suitable for the removal of the phosphorus ions. Therefore, post-treatment procedures were usually combined with biological processes to remove phosphorus in advanced wastewater treatment [5].

CONTACT Tan Tai Nguyen nttai60@tvu.edu.vn

(c) 2020 Informa UK Limited, trading as Taylor \& Francis Group 
A few decades ago, phosphorus was removed from wastewater using a sedimentation method, biological treatments, and chemical precipitations [6,7]. However, they have several drawbacks such as high costs, time-consuming to perform, complicated in operation, and low efficiency in processing [8]. Therefore, adsorption-based methods are the most useful and economical among the various techniques mentioned above due to benefits such as high adsorption capacity, low cost and an environmentally friendly approach $[9,10]$.

Previously, phosphate ion adsorption has been studied based on several adsorption materials, such as slag [5,9], natural soil [11-13], limestone [14,15], zeolite and sand $[16,17]$, Moroccan oil shale [18,19], water treatment fly ash $[1,4,20]$, red mud $[21,22]$, cement [23,24], modified bentonite [25] and calcium bentonite clay mineral [26]. However, some materials mentioned require pretreatment for adsorption. It is worth mentioning also that coal slag (CS) promises adsorptive materials for the removal of heavy metals including $\mathrm{Cd}^{2+}, \mathrm{Cu}^{2+}, \mathrm{Zn}^{2}[27,28]$ and nutrients $[1,29]$. In addition, the $\mathrm{CS}$ is a by-product of a thermal power plant that can cause damage to the surrounding environment and can be harmful to human beings [30]. So, the reuse and recycling process of CS is a cost-effective method that could partially eliminate the disposal problems.

This study investigated the adsorption efficiency of phosphate ion adsorption using CS produced from a thermal power plant. The adsorption method was adopted to efficiently remove phosphate ions under specific controlled conditions, including pH control, contact time, and mass of adsorbent.

\section{Materials and methods}

\subsection{Chemical and reagents}

The CS used was generated from the Duyen Hai 3 thermal power plant (Tra Vinh province, Vietnam). Sulphuric acid $\left(\mathrm{H}_{2} \mathrm{SO}_{4}, 98 \%\right)$, Ammonium molybdate tetrahydrate $\left(\left(\mathrm{NH}_{4}\right)_{6} \mathrm{Mo}_{7}\right.$ $\left.\mathrm{O}_{24.4} \mathrm{H}_{2} \mathrm{O}, 99 \%\right)$, Potassium dihydrogen phosphate $\left(\mathrm{KH}_{2} \mathrm{PO}_{4}, 99.5 \%\right)$, Antimony potassium tartrate hydrate $\left(\mathrm{K}(\mathrm{SbO}) \mathrm{C}_{4} \mathrm{H}_{4} \mathrm{O}_{6} .5 \mathrm{H}_{2} \mathrm{O}, 99.5 \%\right)$, ascorbic acid $\left(\mathrm{C}_{6} \mathrm{H}_{8} \mathrm{O}_{6}, 98 \%\right)$ were purchased from Merck KGaA.

\subsection{Phosphate ions adsorption study}

The CS used was sampled from the Duyen Hai 3 thermal power plant. The drying process consisted of leaving the CS in an oven at $80^{\circ} \mathrm{C}$ for $2 \mathrm{~h}$. Later, it was ground and sieved with a $2 \mathrm{~mm}$ filter porosity size. The CS powder obtained was ready for use to evaluate phosphate removal. Our major factors, including the effect of $\mathrm{pH}$, concentration of adsorbate, contact time, and mass of adsorbent at room temperature were studied for adsorption of phosphate ions. $\mathrm{pH}$ was tested in the range changed from 3 to 9; concentration range from 5 to $30 \mathrm{mg} \mathrm{L}^{-1}$; the mass of adsorbent was set up from 1 to $6 \mathrm{~g}$, and the contact time varied from 15 to 75 min with 15 min increment.

The concentration of the phosphate ions was analysed by using a UV-Vis spectrum analyser. The standard phosphate solution preparation includes the mixing of potassium dihydrogen phosphate with distilled water. A calibration curve of phosphate concentration 
was plotted based on the concentration range of $2 \mathrm{ppm}$. The capacity $\left(Q_{\text {cap }}\right)$ and efficiency $\left(H_{\text {eff }}\right)$ of adsorption were analysed based on Equations 1 and 2.

$$
\begin{gathered}
Q_{\text {cap }}=\frac{C_{\text {in }}-C_{e q}}{m} V \\
H_{\text {eff }}=\frac{C_{\text {in }}-C_{e q}}{C_{\text {in }}} \times 100 \%
\end{gathered}
$$

where $C_{i n}, C_{e q}, V$, and $m$ were the initial concentration, the equilibrium concentration of phosphate ions, the volume of adsorbate and the mass of adsorbent, respectively.

\subsection{Physicochemical and morphological characterisation}

The physicochemical characterisation of CS and adsorption of phosphate ions was obtained using six analytical techniques: X-ray-Fluorescence (XRF, Thermo Scientific ARL QUANT'X) and X-ray Diffraction (XRD, Thermo Scientific ARL EQUINOX 1000X) for the crystallographic structure and chemical composition of CS used; Scanning Electron Microscopy (SEM, Keyence VKX-1000) for ultrastructural analysis; Fourier Transform Infrared Spectroscopy (FTIR, Thermo Scientific Nicolet iS50) for determination of functional groups in a range $4000-500 \mathrm{~cm}^{-1}$; Ultraviolet-Visible Spectroscopy (UV-Vis, Shimazu UV-2600) for measurement of concentration of phosphate solution; pore size distribution obtained by BJH (Micrometrics ASAP 2010), surface area measured by the BET method and Atomic Adsorption Spectrometer (AAS, Varian AA240) for detection of leaching contaminants in wastewater treated.

\subsection{Determination point of zero charge}

The experiments were conducted to measure the $\mathrm{pH}$ at the potential of zero point charge ( $\mathrm{pHpzc}$ ) based on the $\mathrm{pH}$ drift method. The initial $\mathrm{pH}$ of sodium chloride was in the range of 2 to 12 with an increment of $2 \mathrm{pH}$ unit. The CS of $150 \mathrm{mg}$ was added into the above solution for $24 \mathrm{~h}$ with stirring speed of $200 \mathrm{rpm}$. Then, the final $\mathrm{pH}$ was measured and the relation between initial $\mathrm{pH}$ and final $\mathrm{pH}$ was plotted in Figure 3.

\subsubsection{Results and discussion}

The XRD analysis of the CS sample is presented in Figure 1(a). Twelve distinct peaks at $16.37^{\circ}, 20.77^{\circ}, 26.20^{\circ}, 26.54^{\circ}, 30.94^{\circ}, 33.18^{\circ}, 35.16^{\circ}, 36.51^{\circ}, 39.35^{\circ}, 42.38^{\circ}, 50.08^{\circ}$ and $67.87^{\circ}$ are clearly outlined. Those diffraction peaks represent the composition of quartz and mullite. It was confirmed after with a good match when interrogating database in JCPDS file (No. 22-700) [31]. Then, the XRF analysis was conducted to verify the elemental composition of CS. The analysed results indicated that the CS samples are abundant with silica dioxide $\left(\mathrm{SiO}_{2}\right)$ representing up to $56 \%$ of the total amount. This result is in good agreement and comparable to other adsorbent materials reported in the literature, as shown in Table 1. The level of $\mathrm{SiO}_{2}$ in our CS material is promising and could exhibit the required adsorption properties for phosphate. One should note that the CS sample also contains a small proportion of trace metal elements like iron, magnesium, and aluminium, as depicted in Table 1. 

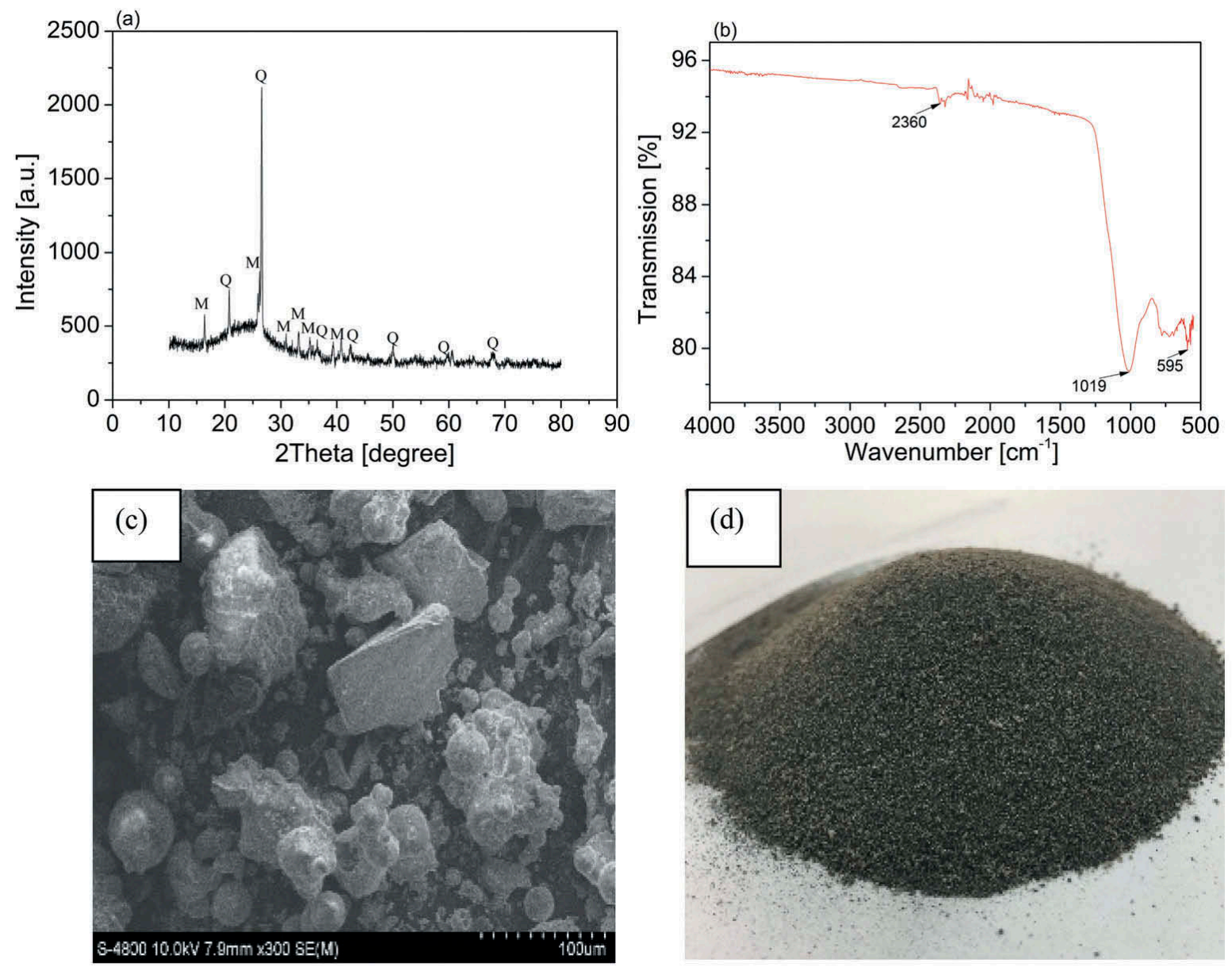

Figure 1. Physicochemical characterisation of CS from Duyen Hai thermal power plant. Note: (a) X-ray diffraction pattern; (b) Fourier transform infrared spectrum; (c) SEM image; (d) Real image.

Table 1. Comparison of the chemical composition between CS used in this study and other materials. Noted: the numbers represent the weight percentage (\%) of each composition.

\begin{tabular}{lcllclllc}
\hline Materials & $\mathrm{Al}_{2} \mathrm{O}_{3}$ & $\mathrm{SiO}_{2}$ & $\mathrm{Fe}_{2} \mathrm{O}_{3}$ & $\mathrm{CaO}$ & $\mathrm{MgO}$ & $\mathrm{K}_{2} \mathrm{O}$ & $\mathrm{TiO}_{2}$ & Source \\
\hline Coal slag & 28.7 & 55.9 & 5.14 & 1.04 & 1.96 & 3.45 & 0.72 & In this study \\
Fly ash & 1.34 & 68.01 & 0.25 & 5.77 & 2.39 & 2.09 & 0.07 & {$[9]$} \\
Iron Slag & 2.31 & 17.57 & 7.22 & 48.43 & 7.84 & 0.04 & 1.15 & {$[9]$} \\
Fly ash & 28 & 49 & 8.3 & 5.3 & 1.6 & 3.70 & 1.1 & {$[38]$} \\
Fly ash & 33.01 & 49.3 & 4.84 & 2.98 & 0.95 & - & - & {$[39]$} \\
Fly ash & 18.61 & 48.59 & 7.99 & 10.91 & 2.76 & 1.73 & 0.97 & {$[39]$} \\
Fly ash & 21.87 & 51.64 & 5.54 & 1.05 & 3.01 & 1.05 & - & {$[41]$} \\
Slag & 12.24 & 32.98 & 7.56 & 5.53 & 1.83 & 0.69 & - & {$[41]$} \\
\hline
\end{tabular}

Figure 1(b) represents the FTIR spectrum of the CS samples. The strong absorption bands at 1019 and $594 \mathrm{~cm}^{-1}$ correspond to the symmetric Si-O-Si vibration and Al-O-Si bond, respectively [32]. Relevant signals on the FTIR spectra of CS were the adsorption bands in the region $550-750 \mathrm{~cm}^{-1}$ (these bands correspond to $\mathrm{AlO}_{6}$ groups or the $\mathrm{Si}-\mathrm{H}$ bond) [33]. These results showed agreement with the XRF analysis as mentioned above. In addition, the surface analysis of SEM showed that CS had a random shape with an averaged diameter of approximately $50 \mu \mathrm{m}$. BET and BJH analyses of CS were carried out and the results gave a specific surface area of $9.20 \mathrm{~m}^{2} \mathrm{~g}^{-1}$ and an average pore size of 

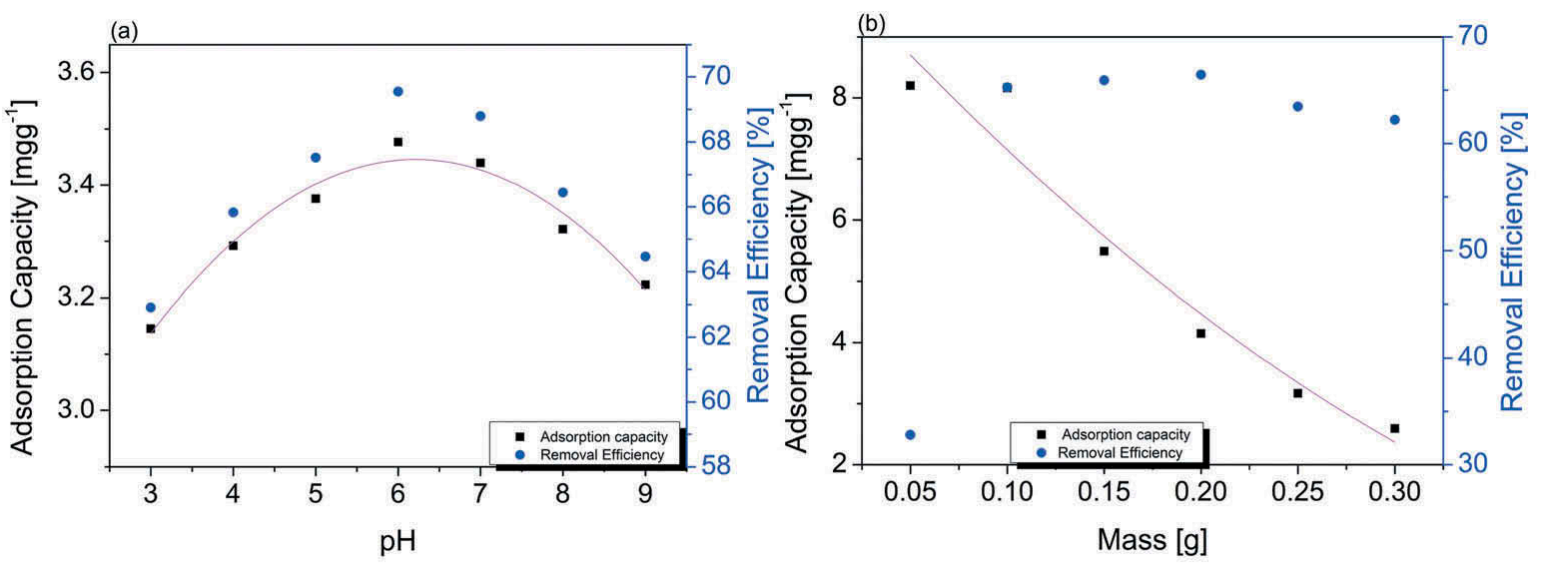

Figure 2. Capacity of phosphate adsorption and efficiency of phosphate removal by CS. Note: (a) Influence of $\mathrm{pH}$; (b) Influence of Mass.

$6.42 \mathrm{~nm}$. All these information indicate that our CS material could be potentially used for removal of phosphate applications.

To obtain the optimised conditions for phosphate removal, the effect of adsorbent mass, the concentration of adsorbate, $\mathrm{pH}$ and contact time were investigated. Only the stirring velocity of $180 \mathrm{rpm}$ was maintained constant during the entire process for mixing of the adsorbent and adsorbate [9] and initial concentration of phosphate ions in aqueous solution is $20 \mathrm{ppm}$. It should be noted that each datapoint in Figures $2(a, b)$ and 4 is represented by the mean value of three experimental results.

The adsorption capacity ( $\mathrm{mg} \mathrm{g}^{-1}$ ) and efficiency of adsorption (\%) for phosphate ion removal by $\mathrm{CS}$ were firstly investigated by varying the $\mathrm{pH}$ change. As seen in Figure 2(a), the removal efficiency of phosphate ion was reached a maximum value of $69.55 \%$ at $\mathrm{pH} 6$, while the removal efficiency dropped down when $\mathrm{pH}$ value was higher or lower than 6 . The $\mathrm{pH}$ increased or decreased, the deformation of phosphate from $\mathrm{H}_{\mathbf{2}} \mathrm{PO}_{\mathbf{4}}{ }^{-}$to $\mathrm{HPO}_{\mathbf{4}}{ }^{2-}, \mathrm{CS}$ surface charge and active sites may prevent phosphate ion adsorption. When $\mathrm{pH}$ increases from 2 to 7 , the concentration of divalent $\mathrm{HPO}_{4}{ }^{2-}$ ion increases ten-fold for each unit in $\mathrm{pH}$ [34]. $\mathrm{HPO}_{4}{ }^{2-}$ with two nucleophilic centres and the potential to act as bidentate ligand may have a greater affinity for the $\mathrm{CS}$ surface than $\mathrm{H}_{2} \mathrm{PO}_{4}{ }^{-}$. The surface of CS contained many active sites $\left(\mathrm{Ca}^{2 \pm}, \mathrm{Mg}^{2 \pm}\right)$, which are able to form precipitation of $\mathrm{Ca}_{3}$ $\left(\mathrm{PO}_{4}\right)_{2}$ or $\mathrm{Mg}_{3}\left(\mathrm{PO}_{4}\right)_{2}$. In acidic $\mathrm{pH}, \mathrm{Ca}^{2 \pm}$ and $\mathrm{Mg}^{2 \pm}$ ions were released more from the CS to precipitate $\mathrm{Ca}_{3}\left(\mathrm{PO}_{4}\right)_{2}$ or $\mathrm{Mg}_{3}\left(\mathrm{PO}_{4}\right)_{2}$. This leads to achieve more significant absorption capacity at $\mathrm{pH} 6$ even though the $\mathrm{CS}$ surface has negative charge. For $\mathrm{pH} \geq 6$, the $\mathrm{CS}$ surface has positive charge as shown in Figure 3. This positive charge of the CS surface could contribute to adsorb of phosphate ion via electrostatic attractive force. However, the increase in concentration of $\mathrm{HPO}_{4}{ }^{2-}$ was slowly down to zero at $\mathrm{pH} \geq 7$ [35]. This may be the reason for the decrease in phosphate ion adsorption as shown in Figure 2(a).

The parabolic shape curve was fitted with a quadratic second-order equation $q=q_{o}+$ $a x+b x^{2}$ to the measured data in Figures $2(a, b)$ and 4 to find the ideal characteristic parabolic shape for phosphate removal with varying parameters including $\mathrm{pH}$, mass and contact time during the adsorption process. The fitting results in Table 2 showed that the minimum possible capacity of phosphate ion adsorption $\left(q_{o}\right)$ based on CS was $2.3 \mathrm{mg} \mathrm{g}^{-1}$ for $\mathrm{pH}$ change (Figure 2(a)); $10.4 \mathrm{mg} \mathrm{g}^{-1}$ for CS mass change (Figure 2(b)), and $8.1 \mathrm{mg} \mathrm{g}^{-1}$ contact 


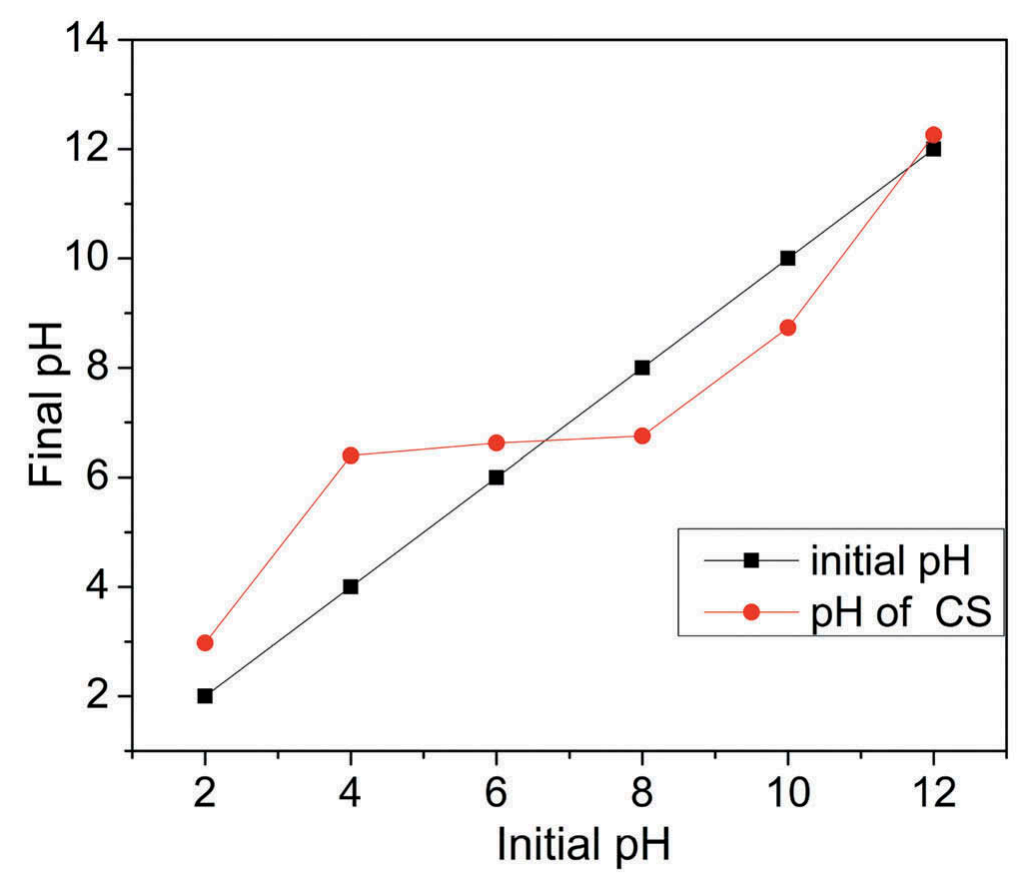

Figure 3. The pHpzc determination curve of the CS.

Table 2. Kinetic parameters in phosphate removal.

\begin{tabular}{lcccc} 
& & \multicolumn{3}{c}{ Fitting coefficients } \\
\cline { 3 - 5 } & Minimum adsorption capacity $\mathrm{q}_{\mathrm{o}}\left(\mathrm{mg} \mathrm{g}^{-1}\right)$ & $\mathrm{A}$ & $\mathrm{b}$ & $\mathrm{R}^{2}$ \\
\hline Time & 8.1 & 0.02 & -1.91 & 0.97 \\
Mass & 10.4 & 35.5 & 29 & 0.92 \\
$\mathrm{pH}$ & 2.3 & 0.37 & -0.03 & 0.95 \\
\hline
\end{tabular}

time change (Figure 4), respectively. Results also showed the minimum possible adsorption capacity in case the $\mathrm{pH}$ drops to a value 4 times lower the different cases. This was caused by the deformation of phosphate from $\mathrm{H}_{2} \mathrm{PO}_{4}{ }^{-}$to $\mathrm{HPO}_{4}{ }^{2-}, \mathrm{CS}$ surface charge and active sites as

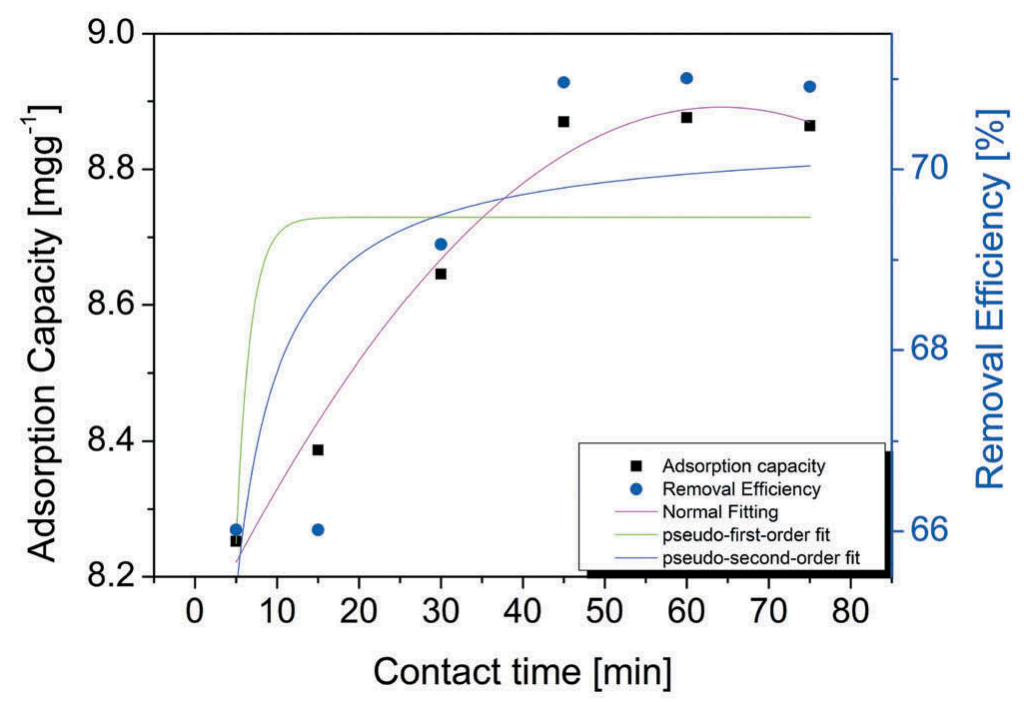

Figure 4. Adsorption kinetics of phosphate ions by CS. 
discussed above. Moreover, all the correlation coefficients $\left(R^{2}\right)$ for three different cases $(\mathrm{pH}$, mass and contact time) were higher than 0.90 , indicating that the model proposed, i.e. the second-order quadratic model, fitted well into the experimental data.

Furthermore, Figure 4 shows the adsorption kinetics of CS. The y-axis on the right of Figure 4 presents the phosphate ion removal efficiency of CS. The figure showed the maximum efficiency of $72 \%$ with the optimised conditions including a contact time of 45 min with a CS loading mass of $0.1 \mathrm{~g}$. As seen in Figure 4, the phosphate ions slowly adsorbed by CS and achieve a plateau value after $45 \mathrm{~min}$. Hence, the initial adsorption rate was estimated at around $1.65\left(\mathrm{mg} \mathrm{min}^{-1}\right)$. It is generally seen that the lower initial adsorption rate is, the longer the equilibrium time is. This relatively low adsorption rate can be attributed to the weak diffusion of phosphate ions from surface adsorption sites to the bulk CS pore, mainly caused by the small pore size of $6.42 \mathrm{~nm}$. The maximum adsorption capacity was experimentally estimated around $9 \mathrm{mg} \mathrm{g}^{-1}$, which is higher compared to other studies published as depicted in Table 4. It is important to note that this higher capacity obtained was mainly due to a large number of oxides (i.e. $\mathrm{CaO}, \mathrm{MgO}$ ) contained in CS with a large surface area. It is worth to mention that leaching contaminants in water treated was investigated by AAS device under optimising adsorption conditions. The result showed that the leaching contaminants contains $\mathrm{Fe}, \mathrm{Al}$ and $\mathrm{Mg}$ with tiny concentrations of $0.93 \mathrm{mg} \mathrm{L}^{-1}, 0.07 \mathrm{mg} \mathrm{L}^{-1}$ and $100 \mathrm{mg} \mathrm{L}^{-1}$, respectively. The higher in concentration of $\mathrm{Mg}$ was due to its high solubility to perform reaction with $\mathrm{HPO}_{4}{ }^{2-}$ as mentioned above.

We investigated the adsorption kinetics by using the experimental data fitted with the pseudo-first-order adsorption kinetic model (Equation 3) and pseudo-second-order adsorption kinetic model (Equation 4) as given below [36].

$$
\begin{gathered}
q_{t}=q_{a d}\left(1-e^{-K_{1} t}\right) \\
q_{t}=\frac{t}{\frac{1}{K_{2} q_{a d}^{2}}+\frac{t}{q_{a d}}}
\end{gathered}
$$

where $q_{a d}$ and $q_{t}$ were the adsorption capacity of phosphate ions at the equilibrium time and $t$, respectively, and $K_{1}$ was the pseudo-first-order rate constant. And $K_{2}$ was the pseudo-second-order rate constant. The adsorption kinetic coefficients obtained by using the non-linear regression are presented in Table 3. Figure 4 presents a comparison between two pseudo adsorption kinetic models and the parabolic model. The possible adsorption capacity of around $9 \mathrm{mg} \mathrm{g}^{-1}$, was comparable for both models, even though the correlation coefficients in the case of the pseudo-kinetic model were smaller than that of the parabolic adsorption model. This result fits quite well with the experimental data, indicating that the 3 models tested including pseudo-first-order adsorption kinetic, pseudo-second-order adsorption kinetics and parabolic adsorption model are suitable for analysis of phosphate adsorption kinetics.

Adsorption isotherm models are essential for the prediction of the procedures to design the adsorption system. Besides, the adsorption capacity could be estimated based on the selection of the approximate amount of adsorbent. In this work, the phosphate concentration was in the range of 5 to $30 \mathrm{mg} \mathrm{L}^{-1}$. The experiment was conducted under optimum conditions (i.e. $\mathrm{pH} 6, \mathrm{CS}$ dosage of $0.1 \mathrm{~g}$ and contact time 
Table 3. Adsorption kinetic coefficients for phosphate removal.

\begin{tabular}{lcccc}
\hline & & \multicolumn{3}{c}{ Kinetic coefficients } \\
\cline { 3 - 5 } & $\begin{array}{c}\text { Possible adsorption capa- } \\
\text { city } q_{a d}\left(\mathrm{mg} \mathrm{g}^{-1}\right)\end{array}$ & $K_{1}\left(\mathrm{~min}^{-1}\right)$ & $\left(\mathrm{g} \mathrm{mg}^{-1} \mathrm{~min}^{-1}\right)$ & $\mathrm{R}^{2}$ \\
\hline $\begin{array}{c}\text { Pseudo-first-order adsorption } \\
\text { kinetic model }\end{array}$ & 8.73 & 0.58 & & 0.39 \\
$\begin{array}{c}\text { Pseudo-second-order } \\
\text { adsorption kinetic model }\end{array}$ & 8.85 & & 0.27 & 0.71 \\
\hline
\end{tabular}

Table 4. Comparison of phosphate adsorption capacity of CS with adsorbent materials.

\begin{tabular}{|c|c|c|c|c|}
\hline Adsorbent & $\begin{array}{l}\text { Concentration range } \\
\left(\mathrm{mg} \mathrm{L}^{-1}\right)\end{array}$ & $\begin{array}{l}\text { Phosphate adsorption capacity } \\
\qquad\left(\mathrm{mg} \mathrm{g}^{-1}\right)\end{array}$ & Treatment condition & References \\
\hline Coal slag & $5-30$ & 8.22 & Raw coal slag & This study \\
\hline Fly ash & $50-2000$ & 3.34 & Raw fly ash & {$[4]$} \\
\hline Steel slag & $11.40-45.59$ & 5.3 & Raw steel slag & [5] \\
\hline Red mud & $0.01-1$ & 0.58 & $\mathrm{HCl}$ treatment, $\mathrm{pH}=5,40^{\circ} \mathrm{C}$ & [22] \\
\hline Steel slag & $10-125$ & 5.3 & Thermally modified slag & [42] \\
\hline
\end{tabular}

of $45 \mathrm{~min}$ at room temperature). Then, the Langmuir (Equation 5) and Freundlich (Equation 6) models were applied to analyse the experimental data, respectively $[37,40]$.

$$
\begin{aligned}
\frac{C_{e q}}{q_{e q}} & =\frac{C_{e q}}{q_{\max }}+\frac{1}{K_{L} q_{\max }} \\
\log q_{e q} & =n \log C_{e q}+\log K_{F}
\end{aligned}
$$

where $C_{e q}$ and $q_{e q}$ were the phosphate ions concentration in solution, and the number of phosphate ions adsorbed at equilibrium, respectively. And $q_{\max }$ was the maximum capacity of adsorption; $K_{L}$ was the energy adsorption; $K_{F}$ was the adsorption capacity; $n$ was the adsorption intensity. The adsorption parameters and correlation coefficients obtained by using Langmuir and Freundlich equations are shown in Table 5. The fitting results based on the Freundlich model (Figure 5(b)) showed that the adsorption intensity ( $n$ ) of 0.84 , which was smaller than one that indicated low speed in adsorption of phosphate ions, which corresponds to the long adsorption time of $45 \mathrm{~min}$ as shown in Figure 4. Also, the Freundlich isotherm described a better fit with the experimental data based on correlation coefficient $\left(R^{2}\right)$, which was higher than that of Langmuir isotherm. Besides, the affinity between CS and phosphate ions $\left(K_{L}\right)$ of $0.51 \mathrm{~L} \mathrm{mg}^{-1}$ represented small initial sorption isotherm slope. It was worth noting that the larger $K_{L}$ produced the faster adsorption of phosphate ions in an approximately linear fashion. However, the plot based on the Langmuir isotherm model (Figure 5(a)) showed nonlinear behaviour at around the lowest concentration $\left(8 \mathrm{mg} \mathrm{L}^{-1}\right)$, accounting for the low initial adsorption rate of $1.65\left(\mathrm{mg} \mathrm{min}^{-1}\right)$ as mentioned above.

Table 5. Phosphate adsorption isotherm coefficients.

\begin{tabular}{lcccccc}
\hline & & \multicolumn{4}{c}{ Isotherm coefficients } \\
\cline { 3 - 6 } & $\begin{array}{c}\text { Maximum adsorption capacity } \\
\left(\mathrm{mg} \mathrm{g}^{-1}\right)\end{array}$ & $\begin{array}{c}K_{F} \\
\left(\mathrm{mg} \mathrm{g}^{-1}\right)\end{array}$ & $n$ & $K_{L}\left(\mathrm{~L} \mathrm{mg}^{-1}\right)$ & $\mathrm{R}^{2}$ \\
\hline $\begin{array}{l}\text { Freundlich isotherm } \\
\text { Langmuir isotherm }\end{array}$ & 21.63 & 1.20 & 0.84 & & 0.93 \\
\hline
\end{tabular}



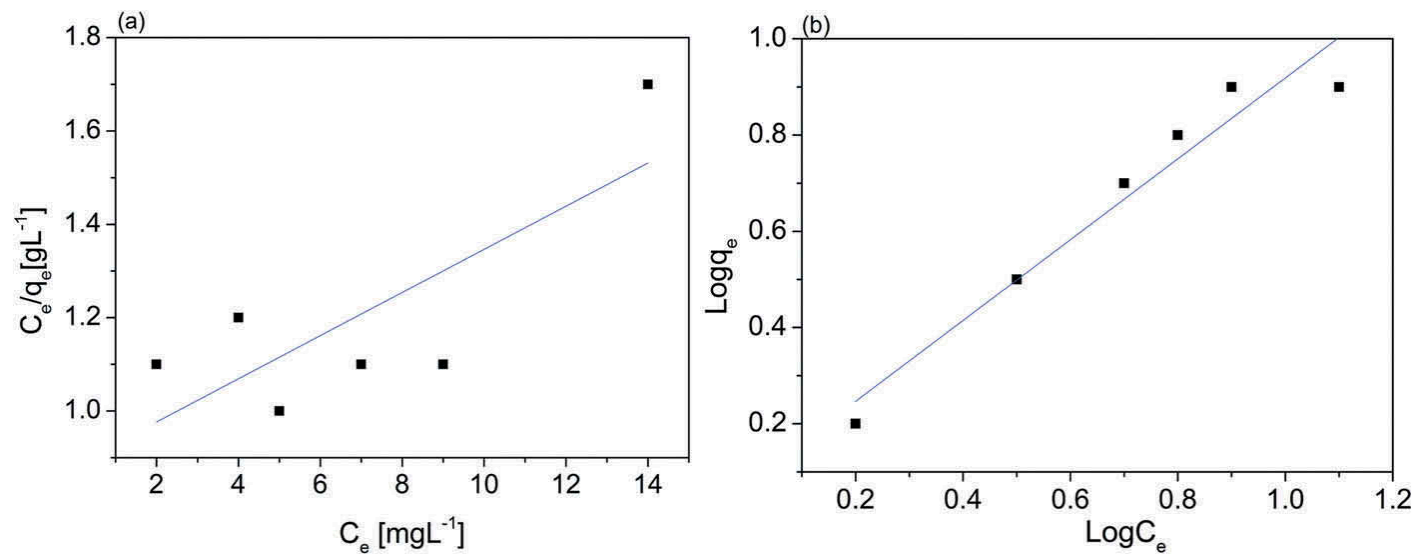

Figure 5. Adsorption isotherms of phosphate by CS. Note: (a) Langmuir isotherm model; (b) Freundlich isotherm model.

Moreover, the maximum adsorption capacity of $21.63 \mathrm{mg} \mathrm{g}^{-1}$ was obtained based on the Langmuir isotherm, implying that the phosphate ions adsorption on CS in our experiment was an effective process for phosphate removal from aqueous solution.

\subsubsection{Conclusion}

This study investigated the adsorption process of phosphate ion from aqueous solution using CS under different conditions such as adsorbent mass, the concentration of adsorbate, $\mathrm{pH}$ and contact time were investigated. The results showed that CS with the surface area of $9.20 \mathrm{~m}^{2} \mathrm{~g}^{-1}$ offered the maximum loading adsorption capacity of $21.63 \mathrm{mg} \mathrm{CS} / \mathrm{g}$ phosphate ion obtained at $\mathrm{pH} 6$, contact time of $45 \mathrm{~min}$ and CS dosage of $0.1 \mathrm{~g}$ without pre-treatment of the CS. In addition, the reuse of CS for phosphate ion adsorption offered several benefits such as low cost adsorbent, less time-consuming method, ease-of-use and partial elimination of the disposal problems.

\section{Data availability statement}

These data used to support the findings of this study are available from the corresponding author upon request.

\section{Disclosure statement}

No potential conflict of interest was reported by the authors.

\section{Funding}

This research was supported by Tra Vinh University under Basic Science Research fund No. [179/HĐ. HĐCN-ĐHTV].

\section{References}

[1] A. Ugurlu and B. Salman, Environ. Int. 24, 911 (1998). doi:10.1016/S0160-4120(98)00079-8. 
[2] I. Oller, S. Malato and J.A. Sanchez-Perez, Sci. Total Environ. 409, 4141 (2011). doi:10.1016/j. scitotenv.2010.08.061.

[3] M. Coma, M. Verawaty, M. Pijuan, Z. Yuan and P.L. Bond, Bioresour. Technol. 103, 101 (2012). doi:10.1016/j.biortech.2011.10.014.

[4] S.G. Lu, S.Q. Bai, L. Zhu, H.D. Shan and J. Hazard, Mater. 161, 95 (2009). doi:10.1016/j. jhazmat.2008.02.123.

[5] J. Yu, W. Liang, L. Wang, F. Li, Y. Zou and H. Wang, J. Environ. Sci. 31, 81 (2015). doi:10.1016/j. jes.2014.12.007.

[6] S.A. Parsons and J.A. Smith, J. Element 4, 109 (2008). doi:10.2113/GSELEMENTS.4.2.109.

[7] H.N. Bhatti, J. Hayat, M. Iqbal, S. Noreen and S. Nawaz, JMRT 7, 300 (2018). doi:10.1016/j. jmrt.2017.08.010.

[8] S. Mignardi, A. Corami and V. Ferrini, Chemosphere 84, 354 (2012). doi:10.1016/j. chemosphere.2011.09.050.

[9] S.M. Ragheb, Hbrc J. 9, 270 (2013). doi:10.1016/j.hbrcj.2013.08.005.

[10] T.T. Nguyen, H.T. Ma, P. Avti, M.J.K. Bashir, C.A. Ng, L.Y. Wong, H.K. Jun, Q.M. Ngo, N.Q. Tran and J. Anal, Methods Chem. ID 6210240, 8 (2019). doi:10.1155/2019/6210240.

[11] E.M. Muindi, J.P. Mrema, E. Semu, P.W. Mtakwa, C.K. Gachene and M.K. Njogu, Int. J. Plant Soil Sci. 4, 203 (2015). doi:10.9734/IJPSS/2015/13037.

[12] J.N. Quinton, J.A. Catt and T.M. Hess, J. Environ. Qual. 30, 538 (2001). doi:10.2134/ jeq2001.302538x.

[13] X. Wanga, R.S. Yost and B.A. Linquist, Soil Sci. Soc. Am. J. 65, 139 (2001). doi:10.2136/ sssaj2001.651139x.

[14] S. Hussain, H.A. Aziz, M.H. Isa, A. Ahmad, J.V. Leeuwen, L. Zou, S. Beecham and M. Umar, Desalin. 271, 265 (2011). doi:10.1016/j.desal.2010.12.046.

[15] M. Zhou and Y. Li, Soil Sci. Soc. Am. J. 65, 1404 (2001). doi:10.2136/sssaj2001.6551404x.

[16] Z. Ganrot, G. Dave and E. Nilsson, Bioresour. Technol. 98, 3112 (2007). doi:10.1016/j. biortech.2006.10.038.

[17] C. Jiang, L. Jia, B. Zhang, Y. He and G. Kirumba, J. Environ. Sci. 26, 466 (2014). doi:10.1016/ S1001-0742(13)60410-6.

[18] S. Mansouri, N. Elhammoudi, S. Aboul-hrouz, M. Mouiya, L. makouki, A. Chham, A. Abourriche, H. Hannache and M. Oumam, Chem. Inter. 4, 7 (2018).

[19] A. Chham, E.H. Khouya, M. Oumam, A. Abourriche, S. Gmouh, M. larzek, S. Mansouri, N. Elhammoudi, N. Hanafi and H. Hannache, Chem. Inter. 4, 67 (2018).

[20] M.Y. Can, E. Yildiz and J. Hazard, Mater. 135, 165 (2006). doi:10.1016/j.jhazmat.2005.11.036.

[21] G. Akay, B. Keskinler, A. Cakici and U. Danis, Water Resour. 32, 717 (1998). doi:10.1016/S00431354(97)00236-4.

[22] W. Huang, S. Wang, Z. Zhu, L. Li, X. Yao, V. Rudolph and F. Haghseresht, J Hazard. Mater. 158, 35 (2008). doi:10.1016/j.jhazmat.2008.01.061.

[23] A.D. Atasoy and M.O. Sahin, Clean: Soil, Air, Water 42, 415 (2014). doi:10.1002/clen.201300074.

[24] X. Wang, J. Chen, Y. Kong and X. Shi, Water Resour. 62, 88 (2014). doi:10.1016/j. watres.2014.05.021.

[25] S. Ghezali, A.M. Benzerdjeb, M. Ameri and A.Z. Bouyakoub, Chem. Inter. 4, 24 (2018).

[26] T.N. Chikwe, R.E. Ekpo and I. Okoye, Chem. Inter. 4, 230 (2018).

[27] B. Bayat and A. Water, Soil Pollut. 136, 69 (2002). doi:10.1023/A:101529603.

[28] V. Hequet, P. Ricou, I. Lecuyer and P.L. Cloire, Fuel 80, 851 (2001). doi:10.1016/S0016-2361(00) 00153-8.

[29] N.M. Agyei, C.A. Strydom and J.H. Potgieter, Cem. Concr. Res. 30, 823 (2000). doi:10.1016/ S0008-8846(00)00225-8.

[30] A. Habib, H. Bhatti and M. lqbal, J. Phys. Chem. 2019. doi:10.1515/zpch-2019-0001

[31] C. Zhou, G. Liu, S. Cheng, T. Fang and P.K.S. Lam, Sci. Rep. 4, 6221 (2014). doi:10.1038/ srep06221.

[32] Y. Cheng, M. Hongqiang, C. Hongyu, W. Jiaxin, S. Jing, L. Zonghui and Y. Mingkai, Constr. Build. Mater. 187, 318 (2018). doi:10.1016/j.conbuildmat.2018.07.220. 
[33] P. Ning, H.J. Bart, B. Li, X. Lu and Y. Zhang, J. Environ. Sci. 20, 670 (2008). doi:10.1016/S10010742(08)62111-7.

[34] W.L. Lindsay and A.P. Schwab, J. Plant Nutr. 5, 821 (1982). doi:10.1080/01904168209363012.

[35] F.J. Kingston, A.M. Posner and J.P. Quirk, Eur. J. Soil Sci. 23, 177 (1972). doi:10.1111/j.13652389.1972.tb01652.x.

[36] J. Ayala, F. Blanco, P. Garcia, P. Rodriguez and J. Sancho, Fuel 77, 1147 (1998). doi:10.1016/ S0016-2361(98)00027-1.

[37] J. Chen, H. Kong, D. Wu, D. Chen, D. Zhang, Z. Sun and J. Hazard, Mater. 139, 293 (2007). doi:10.1016/j.jhazmat.2006.06.034.

[38] D. Panias, I.P. Giannopoulou and T. Perrak, Colloids Surf., A 301, 246 (2006). doi:10.1016/j. colsurfa.2006.12.064.

[39] M. Šešlija, A. Rosić, N. Radović, M. Vasić, M. Đogo and M. Jotić, Geol. Croat. 69, 317 (2016). doi:10.4154/gc.2016.26.

[40] J. Xiong, Z. He, Q. Mahmood, D. Liu, X. Yang, E. Islam and J. Hazard, Mater. 152, 211 (2008). doi:10.1016/j.jhazmat.2007.06.103.

[41] G. Blanchard, M. Maunaye and G. Martin, Water Res. 18, 1501 (1984). doi:10.1016/00431354(84)90124-6.

[42] C. Gerente, V.K.C. Lee, P. Le Cloirec and G. McKay, Rev. Environ. Sci. Technol. 37, 41 (2007). doi:10.1080/10643380600729089. 